This item was submitted to Loughborough's Research Repository by the author.

Items in Figshare are protected by copyright, with all rights reserved, unless otherwise indicated.

\title{
Situational crime prevention and its discontents: rational choice and harm reduction versus 'Cultural Criminology'
}

PLEASE CITE THE PUBLISHED VERSION

PUBLISHER

@ Loughborough University / Journal Compilation @ Blackwell Publishing Ltd

VERSION

AM (Accepted Manuscript)

LICENCE

CC BY-NC-ND 4.0

\section{REPOSITORY RECORD}

Farrell, Graham. 2019. "Situational Crime Prevention and Its Discontents: Rational Choice and Harm Reduction Versus 'cultural Criminology'”. figshare. https://hdl.handle.net/2134/5803. 
This item was submitted to Loughborough's Institutional Repository (https://dspace.lboro.ac.uk/) by the author and is made available under the following Creative Commons Licence conditions.

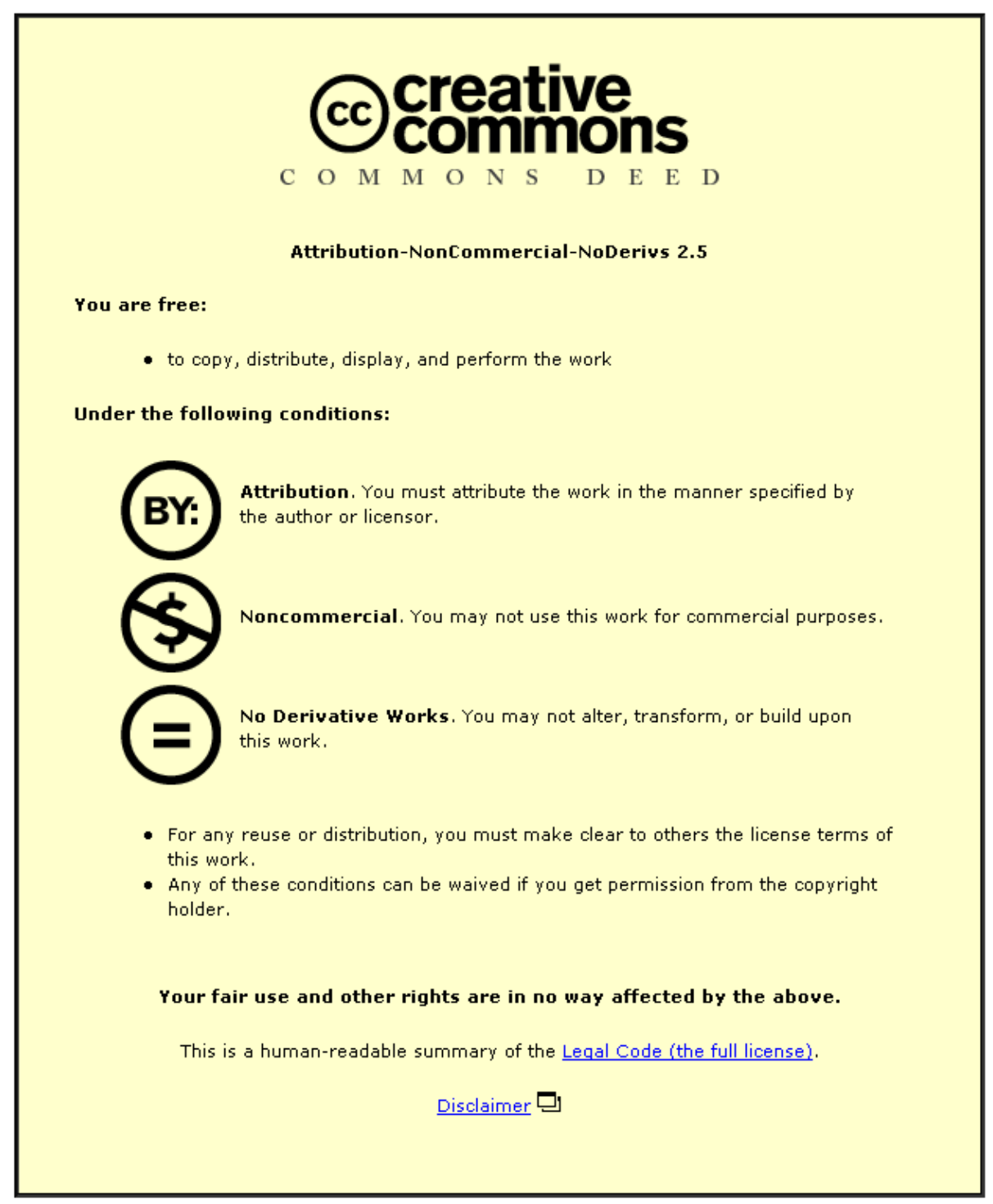

For the full text of this licence, please go to: http://creativecommons.org/licenses/by-nc-nd/2.5/ 


\title{
Situational Crime Prevention and Its Discontents: Rational Choice and Harm Reduction versus 'Cultural Criminology'
}

\author{
Graham Farrell \\ Midlands Centre for Criminology and Criminal Justice \\ Loughborough University, LE11 3TU. \\ Email: g.farrell@lboro.ac.uk
}

This paper was published as: Farrell, G. (2010) 'Situational crime prevention and its discontents: Rational choice and harm reduction versus 'Cultural Criminology' Social Policy and Administration, 44(1): 40-66.

\begin{abstract}
In this journal, in 2007, Keith Hayward criticized situational crime prevention (SCP) and rational choice. The main thesis was that SCP cannot tackle expressive crimes of anger, hostility and excitement. The secondary thesis was that this was because the rational choice perspective cannot account for intangible aspects of offender decision-making. Hayward's cultural criminology was offered as better explaining expressive and other crimes. The present article suggests fundamental issues may have been overlooked. Some of the many ways SCP applies to expressive and irrational crimes, and how readily they fit into the choice framework, are outlined, and a preliminary critique of Hayward's cultural criminology is offered
\end{abstract}

Keywords: Criminal justice; Situational crime prevention; Rational choice; Cultural criminology; Consumerism 


\section{Introduction}

Shoplifting is a victimless crime, like punching someone in the dark.

(Nelson Muntz ${ }^{1}$ )

In volume 41 of this journal, Keith Hayward's (2007) 'Situational crime prevention and its discontents: rational choice theory versus the "culture of now", 2 launched a most enthusiastic attack upon situational crime prevention (SCP) and rational choice. They were variously impaled as, among other things, 'deracinated' (p. 233) and 'hollow' (p. 232), based on 'taken-for-granted assumptions' (p. 245) that 'lack reflexivity' (p. 233), making them 'blind' (pp. 244, 246) and a 'major step back' (p. 236). These are strong words for an academic study in any domain. As such, one would expect them to be based on rigorous argument and overwhelming evidence.

Hayward's main thesis was that SCP cannot prevent crimes that are deemed expressive. Expressive crimes are those which contain a significant emotional element such as anger, hostility and excitement. It was observed that 'much of the critical element of this article turns around the distinction between expressive crimes and those that can be described as "acquisitive”' (p. 238), with SCP restricted to the prevention of acquisitive and property crimes that are the 'stock in trade' (p. 237) of choice theorists. Fortunately, however, expressive crime is a key focus of cultural criminology, the perspective upon which Hayward's critique was based.

The secondary thesis of the article was that the rational choice perspective fails to account for emotional or other intangible aspects of decision-making. This is summarized in the statement that 'not all actors are economically self-interested' (p. 233). This failing is surely why SCP cannot prevent expressive crime: since choice theory only incorporates notions of monetary rewards and not other aspects of decision-making, SCP can only focus on acquisitive or property crime. So burglary might be tackled by SCP but not joyriding because it has no monetary goal. This secondary thesis was underpinned by a set of specific criticisms that deem choice theory conceptually limited, restricted in its incorporation of issues such as impulsivity and irrationality, and unable to adapt to recent criticism.

It was further proposed that expressive crimes of various sorts have increased greatly in recent years, and thereby implied that SCP is of decreasing relevance. The increase in expressive crime was explained as the result of a 'culture of now', because selfish consumerism has spawned alienated 'sensation-gatherers' (p. 239) and 'urbanadventurer criminals' (p. 244). Fortunately, these are key concepts of the cultural criminologist. A large number of expressive and sensation-gathering crimes are touched on by Hayward, many summarized here as table 1. It was concluded that most criminology must seek to learn from cultural criminology if it is to remain relevant and account for the growing crime problem - and not just expressive crime because cultural criminology is equally at home when explaining all crime types (p. 238).

An introductory note is warranted on the style of the 2007 article. In addition to what seem to be derisive terms mentioned in the opening paragraph, aspects of the work appear curiously designed. For example, though the article purports to focus on expressive crime, this appears to become a platform to cast aspersions on all of situational crime prevention and choice theory. It was noted that 'despite considerable success in combating certain forms of economic/acquisitive criminality ... much of this RCT inspired SCP lacks reflexivity' (pp. 232-3). The start of the sentence appears to be a compliment but the criticism at the end negates it and effectively 
refers to all aspects of SCP. In the Conclusions a similar compliment to SCP is sandwiched between one sentence that labels it 'blind' (p. 244) and implies by association that it 'strangles everyday life' (p. 244) and another asserting it is based on 'taken-for-granted assumptions' (p. 245) and that it does not 'comprehend' or 'even acknowledge' (p. 245) contemporary concerns about risk and insecurity. More generally, SCP and related perspectives are discussed as having 'beliefs' (pp. 235, 238, 243, 246), with beliefs elsewhere defined as 'religious and metaphysical' (p. 242). Consequently, when Ken Pease is described as a 'high priest' (p. 234), this seems aimed at associating unscientific qualities with his work. Likewise, Ronald V. Clarke is identified as the leading proponent (p. 235) of the same SCP and rational choice that are derided as hollow, blind and a major step back, and Marcus Felson's work is complimented as 'seminal' (p. 244) but its foundation undermined as 'proceeding with the belief that criminal motivation is a given' (p. 235). ${ }^{3}$ Perhaps this is cultural criminology's accepted style, but to the present writer the compliments seem disingenuous while other aspects might be interpreted as close to ad hominem argument. To suggest these examples were the result of accident or coincidence would surely do an injustice both to Dr Hayward's rhetorical skill and to the laws of probability.

\title{
Table 1: Hayward's list of 'expressive' and 'sensation-gathering' crimes
}

\author{
Joyriding \\ Drug use \\ Football hooliganism \\ Fire-setting \\ Street robbery \\ Binge drinking \\ Gang-related crime, gang membership \\ Peer-group fighting \\ Child molestation \\ Rape \\ Drunken assault \\ Happy slapping \\ Graffiti \\ Skateboarding \\ Illegal BASE jumping \\ Train surfing \\ Parkour 'free runners' \\ 'Street protesters' \\ 'Other urban-adventurer criminals'
}

Source: Hayward (2007: 237, 239, 244).

This rejoinder to the 2007 article has four main sections, then a short conclusion. By means of introduction to the subject, an overview of the situational approach is first. This is followed by a section showing that many situational measures have been used to prevent the crime types listed in table 1, then a review of Hayward's criticisms of the rational choice perspective, and some preliminary examination of the perspective known as cultural criminology. 


\section{The Situational Approach to Social Policy, Reducing Social Harm and Improving Quality of Life}

The 'situational' approach seeks to reduce society's harms and improve quality of life by modifying the design of products, systems and environments. This can range from simple and cheap measures to complex, expensive technologies. In health contexts, a simple measure is the removal of salt cellars from the table - high blood pressure being a common problem. Another is the use of condoms to block the spread of disease. Situational measures to tackle cancer include increasing tobacco taxes and banning smoking in public places. In fire safety, some people will smoke in bed despite the warnings, so we encourage fire-retardant mattresses and smoke alarms. In road safety, situational measures are particularly prevalent, from every traffic light and speed bump, to airbags that reduce injury on impact. A simple characterization of aspects of the situational approach is the popular aphorism that 'it is easier to act yourself into a new way of thinking than to think yourself into a new way of acting' (Anonymous ${ }^{4}$ ). Encouraging people to want to drive better is laudable but proves difficult after a point, while there are immense social gains from designing cars, roads and road furniture to reduce the frequency and severity of crashes. Many measures promote better driving, as when 'Children Crossing' signs stimulate conscience, and road safety is an area with much criminological overlap. One of the present writer's favourite situational tactics is the little bumpy nodules (rumble strips) at the edge of the motorway that awaken slumbering drivers to stop them becoming more dangerous or criminal drivers.

In an ideal society, able-bodied persons would be good enough not to park near the entry door, leaving spaces for those with limited mobility. Instead, disabled parking spaces are designated to encourage community responsibility and remove excuses for accidental antisocial parking (see Godson and Farrell 2005 for a survey of related measures on a university campus). Table 2 gives a tip-of-the-iceberg glimpse of situational measures in a range of social policy contexts. ${ }^{5}$

In environmental climate control, situational measures include catalytic converters, recycling technologies, renewable power (wind, tidal, solar) and various regulatory systems and other measures to encourage them such as carbon offset schemes, tax-breaks for environmentally friendly behaviour or increased taxes for pollution. The notion that the 'polluter pays' is well known in climate control and is an emerging area in crime prevention: imagine, for example, if mobile phone manufacturers and networks, who bear almost none of the huge social cost of phone theft and robberies, could be encouraged to design safer phones and systems to reduce and internalize their 'pollution' (see Pease 1998; Clarke and Newman 2005; Home Office 2006, on incentivization and corporate social responsibility). Likewise, situational measures are often used to tackle other 'crimes of the powerful'. This includes strategies such as product testing to protect consumers, audits to prevent white-collar crime, technology and systems to reduce abuse of power by police and others, and regulatory systems to reduce collusion and price-fixing. SCP, like situational social policies more generally, is necessarily interventionist. It seeks to tackle market failure which over-provides harm and under-provides safety. Politically, for the present writer, it has much in common with the 'liberal paternalism' of Nudge (Thaler and Sunstein 2008). With respect to the economic recession under way at the time of going to press, improved financial regulation may prove the relevant situational measure to prevent recurrence. 
Table 2: Situational measures to reduce harms and improve quality of life

\begin{tabular}{|c|c|}
\hline Context & Examples \\
\hline Road safety & $\begin{array}{l}\text { Speed limits; driving on one side of road; safety belts; } \\
\text { crumple zones; prohibition of injury-causing bonnet } \\
\text { ornaments; traffic lights; airbags; indicator lights; pelican } \\
\text { crossings; 'traffic-calming' measures; cycle helmets; cycle } \\
\text { paths }\end{array}$ \\
\hline Child protection & $\begin{array}{l}\text { Child-proof lids on toxic substance containers; 'safe’ toys } \\
\text { without swallowable parts or lead paint; fire-guards; stair- } \\
\text { guards; school crossing guards }\end{array}$ \\
\hline $\begin{array}{l}\text { Health and safety at } \\
\text { work }\end{array}$ & $\begin{array}{l}\text { Safety helmets; protective guards on machinery; work time } \\
\text { limits }\end{array}$ \\
\hline Climate control & $\begin{array}{l}\text { Catalytic converters; recycling; patent protection for safe- } \\
\text { emissions technologies; tradable permits, feed-in tariffs and } \\
\text { other market-based incentives; cleaner power technologies } \\
\text { (wind, tidal, solar) }\end{array}$ \\
\hline Food safety & $\begin{array}{l}\text { Content and temperature-sensitive labels; tamper-proof } \\
\text { containers; best-before and use-by dates; restrictions on } \\
\text { additives; quality control checks }\end{array}$ \\
\hline Fire safety & $\begin{array}{l}\text { Fire-retardant materials; safety matches; fire doors; fire } \\
\text { extinguishers; escape-route maps; maximum population } \\
\text { policies in night clubs }\end{array}$ \\
\hline Crime & $\begin{array}{l}\text { Garden hedges that define territory; self-locking front doors; } \\
\text { immobilizers; barcodes; car licence plates; property marking; } \\
\text { entry-phones; office receptionists (see many papers in the } \\
\text { Crime Prevention Studies series) }\end{array}$ \\
\hline Health & $\begin{array}{l}\text { No salt on dining table; calorie content labelling; condoms; } \\
\text { increased tobacco prices; smoking bans; surgeons’ face- } \\
\text { masks; opt-out organ donation }\end{array}$ \\
\hline Disability & $\begin{array}{l}\text { Disabled parking bays; many measures mandated under the } \\
\text { Disability Discrimination Act }\end{array}$ \\
\hline Sports & $\begin{array}{l}\text { Electronic timing; slow motion replays; weigh-ins; drug tests; } \\
\text { provision of facilities }\end{array}$ \\
\hline Education/academia & $\begin{array}{l}\text { Anonymous marking; peer-review; external examiners; } \\
\text { professional body practising requirements. }\end{array}$ \\
\hline Drugs & $\begin{array}{l}\text { Legal drugs: Medical licences; drug trials; systems to prevent } \\
\text { diversion. Illegal drugs: Provision of bleach or clean needles; } \\
\text { safe injection 'shooting galleries'; testing pills for impurities }\end{array}$ \\
\hline Trading standards & $\begin{array}{l}\text { Taximeters; fixed-price fares; weighbridges (to tackle goods- } \\
\text { vehicle overloading); kite-marks and quality control; Weights } \\
\text { and measures checks generally }\end{array}$ \\
\hline Art & $\begin{array}{l}\text { Art Loss Register; signatures ('tags' for graffiti); provenance } \\
\text { establishment. }\end{array}$ \\
\hline
\end{tabular}

Situational prevention across the spectrum largely bypasses blame or punishment for harmful behaviour and, instead, seeks to design it out. Cornish and Clarke (2003) have so far identified 25 techniques of SCP. The framework can be used to classify existing practices so that, for example, priority police alarms installed at the homes of survivors of domestic violence invoke the technique of 'enhancing 
surveillance' while empowering victims, providing a breathing space to develop a safety strategy while remaining at home in safety (Lloyd et al. 1994; Erez and Ibarra 2007). Livestock branding is an age-old form of the technique 'identifying property' which parallels parts-marking in cars. Disguising your pricey laptop with a scruffy bag is 'target concealment', as is an unmarked bullion van. And much SCP, like situational measures elsewhere in social policy, is a taken-for-granted part of everyday life - think of separate toilets for women and men (the technique of 'deflecting offenders'). And the best SCP can change the default to be secure, unobtrusive and liberating - so modern cars have auto-locking and immobilizers as the easy default rather than tedious locking of individual door-knobs and an ugly addon steering wheel brace. The interested reader is encouraged to look at the interactive table of the 25 techniques of situational prevention, giving far more crime-related examples, available via the excellent website of the Center for Problem-Oriented Policing. ${ }^{6}$

\section{Preventing Expressive Crime}

If you haven't contemplated murder, you ain't been in love. If you haven't seriously thought about killing a muthaf***a, you ain't been in love. If you haven't had a can of rat poison in your hand, and looked at it for 45 minutes straight, you ain't been in love. If you haven't bought a shovel and a bag, and a rug to roll their fat ass up in, you ain't been in love. If you haven't practised your alibi in front of the mirror, you ain't been in love. And the only thing that stopped you from killing this muthaf***a - was a episode of CSI. Oh man, they're thorough. I'd better make up - they might catch my ass. (Chris Rock, stand-up comedian ${ }^{7}$ )

This section explains how SCP can be applied to crimes that Hayward deems expressive. In passing, it touches on elements of how such crimes are incorporated within choice theory. Joyriding, hooliganism and graffiti are tackled as three popular 'expressive' crimes, happy slapping as a relatively new crime so that change and adaptation are included, and child sex offending because it appears as one of the most difficult crime types to address. For the sake of brevity, only these five of the crimes in table 1 are addressed below, but the same type of analysis could be applied to all the others.

\section{Joyriding}

The 'joy' in joyriding derives from the thrill of the chase plus the prestige among peers and passengers. Taking a car is instrumental, a means to that end (Cornish 1994). Speed-bumps and traffic calming are situational measures that reduce the joy. Better door locks, remote and auto-locking reduce the chances that a door might be unlocked or easily jimmied (Southall and Ekblom 1985). Secure car parks ${ }^{8}$ with, inter alia, barriers, CCTV, attendants and clear sight-lines reduce theft opportunities (Webb et al. 1992). GPS tracking is used to locate stolen cars. Traffic cameras can provide photographic evidence and so deter thieves (PA Consulting 2004). There has been more than one evaluation of steering column locks (Mayhew 1992; Webb 1997). More effective recent immobilizers mean cars cannot be driven away even if a break- 
in succeeds (Brown 2004). With respect to choice theory, some of these situational measures increase the perceived and actual cost of committing the offence. Others reduce the perceived and actual rewards.

Perhaps the most interesting omission from Hayward's analysis is any recognition that car theft in England and Wales fell by 61 per cent in the decade to 2007 even with far more cars on the road (Taylor et al. 2007: 77), and that this was primarily a reduction in taking for joyriding and transportation rather than permanent theft (Brown and Thomas 2003; Brown 2004; Webb 2005). Society has fewer joyrides but far more joy.

\section{Football hooliganism}

Many fans travel on designated coaches, and others are escorted from rail and other stations to reduce altercations during transit, while those with cars are encouraged to park in stewarded parking. Attendance bans restrict the access of known hooligans to games. In a stadium, fans are segregated and monitored by multiple stewards, CCTV and targeted photography, and alcohol is often controlled. When a game ends, crowd dispersal is staggered, to allow one team's supporters to leave first, and supervised. All-seater stadiums were a situational measure introduced after the Hillsborough disaster, as recommended by the Taylor Report (Taylor 1990). Due at least in part to such measures, '[t]here has been a long term decline in hooliganism since the mid1980s' (University of Leicester 2001). The definitive account of SCP and British hooliganism may remain to be written, ${ }^{10}$ and football hooliganism still exists, but Hayward's suggestion that situational measures are irrelevant is quite surprising.

\section{Graffiti}

One renowned graffiti-writer, alleged to be Robin Gunningham from Bristol (BBC 2008), trademarked his alter ego as Banksy. One of his pieces sold for $£ 288,000$ in 2007 (BBC 2007). He is talented and now wealthy, but when he started out the primary reward was likely to have been psychological. It is this psychological reward which is the common factor across all types of graffiti. In the 'rational' offending decision, the reward is the sensation experienced as satisfaction and thrill in knowing that other people must view it, which Martha Smith's (2003) review identifies as a form of control. Where the graffiti is sufficiently sophisticated that it carries a signature tag, there is the extra reward of the kudos from friends and peers or, in Banksy's case, the media. When graffiti is undertaken as a form of persecution the offender is rewarded by knowing the victim will suffer both psychologically and monetarily. Racist graffiti is often repeatedly targeted against the same victims as a component of prolonged intimidation and victimization (Sampson and Phillips 1995). The rewards of gang graffiti include not just recognition but also intimidation and turf-marking (Spicer 2007). And while most graffiti is vandalism, not art, it remains the case that, from the more prevalent nasty everyday scrawl to the most sophisticated, it all fits easily into the cost-benefit framework of choice theory.

In the present context there is no little irony in the fact that graffiti artists use signature tags to retain their informal intellectual ownership. This is the situational technique of 'identifying property'. But more importantly, there is an abundance of situational measures to tackle graffiti and other vandalism. They can be as simple as 
graffiti boards which are easily cleaned or replaced, anti-graffiti paint and surfaces, and restrictions upon the sale of spray cans, and they range to painting a wall a different colour, routine repainting (akin to cleaning), imposing a pre-emptive mural, better management of void properties, improving sight-lines for natural surveillance, and alley-gating to block access to vulnerable targets. Kelling and Sloan-Hewitt's famous 1992 study showed how regular cleaning of New York subway cars reduced graffiti. Clean cars meant graffiti writers did not receive the reward of knowing thousands of commuters would view their work. Many of them quit and there was little displacement - the scratching of subway car windows being less serious and 'displacement' to photography being welcomingly positive (Snyder 2006). More recently, the city of Vancouver claims an 80 per cent reduction in graffiti over a threeyear period, having implemented a portfolio of measures via a multi-agency partnership (Spicer 2007). There is a range of guides on tackling graffiti and other forms of vandalism and criminal damage available from the Home Office. ${ }^{9}$ Vandalism fell 19 per cent in England and Wales in the decade to 2006 (Hoare and Cotton 2006: 95).

\section{Happy slapping}

Happy slapping is an assault filmed by mobile phone (Akwagyiram 2005).

Distributing the video brings an extension of the psychological reward to offenders in the form of kudos, and can impose further psychological costs on victims. Happy slapping is caused by the new criminal opportunity presented by mobile phones with video facilities, with the Internet providing a means of distribution. The potentially larger audience may bring greater reward, but otherwise it remains a form of bullying and criminal assault. There are both specific and general situational responses. There are restrictions on the distribution of violent videos on public Internet sites such as YouTube. Mobile phone cameras facilitate evidence collection by victims and others. In addition, proud offenders might be captured on their own film, and video uploads might be traced to their source. Bullying is often repeated and concentrated in and around particular locations such as schools (Farrington 1993; Pitts and Smith 1995), so measures to prevent repetition such as changing routes and timings, may be appropriate. Routine precautions (Felson and Clarke 1995) such as being accompanied by friends can act as a situational deterrent. Assaults are contained by many measures in public and private settings. Bars and clubs can design layouts and management policies to reduce assault opportunities, urban areas can be shaped to influence the flow of people, and taxis and public transport can operate in ways that reduce opportunities for assault (see e.g. Homel 1997).

It is clear that situational responses to happy slapping, as with many forms of assault and social disorder, are in their infancy. Future situational responses may include intelligent software that identifies movements (based on stance, gait, eye contact) that are the signature of violence or its precursors (Darker et al. 2007). That SCP should seek to anticipate and adapt as crime changes is a critical component of the approach (Ekblom 1997, 1999; Pease 1997). 


\section{Child sexual abuse}

'Child molestation' is on Hayward's list of expressive or sensation-gathering crimes where SCP may have 'inherent problems ... . when trying to devise initiatives to stem offences' (p. 237). Much child sexual assault is by familiars - family, friends and trusted others - whose choice is facilitated by easy access to vulnerable targets (reducing effort and risks). Would-be child sex offenders may take jobs as children's sports coaches, priests, or other posts which provide access. Society is gradually developing its repertoire of situational responses, from routine precautions such as accompanying children, and the 'buddy system' (all about personal safety), to employee background checks, teaching parents and security staff to recognize grooming, the monitoring of Internet chat rooms, glass panels in interview room doors, and supervision of intimate tasks such as bathing (Wortley 2006). These are a few of many. The reader is referred to the set of studies in Wortley and Smallbone's book Situational Prevention of Child Sexual Abuse (2006; see also Smallbone and Wortley 2001; Beauregard and Leclerc 2007; then work backwards through the literature on 'rational' decision-making by sex offenders).

\section{Discussion}

Expressive crime sits readily within a rational choice framework and there are too many relevant SCP measures to trawl through them here for each of Hayward's expressive crimes. There is clearly much work to be done in the development of situational responses to these and many other crimes, but it does not follow that the approach and theory are not applicable.

\section{Rational Choice}

This section has three parts. It looks more closely at Hayward's critique of the rational choice perspective.

\section{How to build a robust theory}

Hayward expresses concern that the SCP and rational choice perspective 'lacks reflexivity' (p. 233). By this, he appears to suggest there is a failure to adapt to changing knowledge, circumstances and criticism. Some light might be shed upon the issue by reference to the useful list of key developments in choice theory provided by McFadden (2000), shown as table 3.

Rather than 'lacking reflexivity', McFadden's summary shows how the field is characterized by debate, adaptation and progress, as the theory grows and adapts to incorporate new knowledge. Along similar lines, Kahneman (an author whom Hayward refers to in passing on p. 234) observed in relation to bounded rationality:

It is encouraging to note, however, that the challenge of incorporating the first wave of psychological findings into economics appeared even more daunting 20 years ago, and that challenge has been met with considerable success (Kahneman [2003]: 1470) 
Table 3: Summary of cognitive effects in decision-making

\begin{tabular}{|c|c|}
\hline Effect & Description \\
\hline Anchoring & Responses are influenced by cues contained in the question \\
\hline Availability & $\begin{array}{l}\text { Responses rely too heavily on readily retrieved information, and } \\
\text { too little on background information }\end{array}$ \\
\hline Context & Previous questions and interviewer interaction colour perception \\
\hline $\begin{array}{l}\text { Framing/reference } \\
\text { point }\end{array}$ & $\begin{array}{l}\text { Question format changes saliency of different aspects of the } \\
\text { cognitive task }\end{array}$ \\
\hline Focal & Quantitative information is stored and/or reported categorically \\
\hline Primary/recency & Initial and recently experienced events are the most salient \\
\hline Projection & $\begin{array}{l}\text { Responses are consonant with the self-image the subject wishes } \\
\text { to project }\end{array}$ \\
\hline Prospect & $\begin{array}{l}\text { The likelihoods of low-probability events are misjudged, and } \\
\text { treated either as too likely or as zero }\end{array}$ \\
\hline Regression & $\begin{array}{l}\text { Causality or permanence are attached to past fluctuations, and } \\
\text { regression to the mean is underestimated }\end{array}$ \\
\hline Representativeness & $\begin{array}{l}\text { High conditional probabilities induce overestimates of } \\
\text { unconditional probabilities }\end{array}$ \\
\hline Rule-driven & Motivation and self-control induce strategic responses \\
\hline Saliency & The most salient aspects of the question are overemphasized \\
\hline Status quo & Current status and history are privileged \\
\hline Superstition & Elaborate causal structures are attached to coincidences \\
\hline Temporal & Temporally inconsistent time discounting \\
\hline
\end{tabular}

Source: From McFadden (2000: 347).

The dialectical process of criticism and revision that is noted by McFadden and Kahneman is the signature of a robust and reflexive (in Hayward's terms) theory. Consider Darwin's theory of evolution (1859). It has been refined over time, and proponents debate among themselves; the debate between Stephen Jay Gould and Richard Dawkins over the specifics of evolutionary progress was perhaps the best known (see e.g. Dawkins 2003). Nevertheless, evolution remains the most convincing explanation of life on earth. In relation to choice theory, McFadden concluded that much empirical work remains to be done to keep up with theory and continue the iterations of development and improvement:

The potentially important role of perceptions, ranging from classical psychophysical perception of attributes, through psychological shaping of perceptions to reduce dissonance, to mental accounting for times and costs, remains largely unexplored in empirical research. (McFadden 2001: 373-4)

The work of McFadden and Kahneman is not criminology, but is about human choices, heuristics and departures from strict rationality. Such thinking influenced criminological choice theory from the outset: Cornish (1978), for example, discusses Tversky (1967) and Tversky and Kahneman (1974) at length. There is certainly tremendous scope to progress the rational choice approach to offending, not least because it is a metatheory (Cornish 1993) that dovetails well with dispositional theories of offending via the concepts of preferences and constraints (see also Cornish and Clarke 1986; Felson 1986; Tibbetts and Gibson 2001). But the reasoning criminal 
and the intuitive and irrational criminal are compatible theoretical concepts. When writers such as Ronald Clarke, Derek Cornish and Ken Pease (key subjects of Hayward's article) use choice theory, it is as a frame for informing the development of crime prevention, and they use the theory in a rather modest, understated fashion. This is because they know rational choice is a powerful vehicle and that criminology still drives it in second gear or, in the case of many criminologists, into the nearest tree.

\section{Intangible costs}

An assertion that Hayward offers as a criticism of the rational choice perspective is that 'not all actors are economically self-interested' (p. 233). The crux of the issue here is the definition of the term 'economically self-interested'. Hayward seems to suggest that some decisions involve more than money but that choice theory only includes decisions relating to money. Yet the term 'economic' incorporates all elements of a decision, whatever they are, including all aspects of non-monetary costs. That is why the textbook model of economic decision-making is one of utility maximization, not income or money maximization. Hence psychological costs, including expressive emotional elements and sensations, are a critical component in determining whether something is economic.

Monetary gain is a goal of acquisitive crime. However, benefits from crime are often psychological or non-monetary and are known as intangible costs. Burglars and robbers report experiencing a rush (Feeney 1986; J. Smith 2003; Nee and Meenaghan 2006). The non-monetary benefits of crime can include the perceived reward of being able to control another individual through violence or threats or graffiti, the thrill of committing a crime or impressing potential sexual partners or onlooking peers. Many such elements were touched on in the review of examples of 'expressive' crimes above, and are summarized in table 4. Perceived benefits from committing a crime can be subjective, reflecting personal preferences. However, it is clear that choice theory, via this cost-benefit calculation, applies across crime types.

In the broader field of cost-benefit analysis, there have been advances in the estimation of the intangible costs of crime and fear. The focus to date has been on these costs as experienced by victims (Miller et al. 1996; Cohen 2000; Cohen et al. 2004; Dolan et al. 2005; Atkinson et al. 2005; Dubourg et al. 2005). There is certainly scope for improvement and for developing estimates of intangible costs involved in offending decisions. However, this does not mean the theoretical framework does not allow for their inclusion or that it cannot be used to inform situational responses. 
Table 4: Types of perceived cost and benefit of committing crime

\begin{tabular}{|c|c|c|}
\hline & Costs & Benefits \\
\hline Monetary & $\begin{array}{l}\text { Expenditure on tools } \\
\text { - Cost of travel to } \\
\text { offence site } \\
\text { Possible opportunity } \\
\text { cost of time } \\
\text { (including: learning } \\
\text { skills, search time, } \\
\text { committing the crime } \\
\text { and escaping) }\end{array}$ & $\begin{array}{l}\text { - Cash } \\
\text { - Goods that can be used, } \\
\text { exchanged or sold }\end{array}$ \\
\hline $\begin{array}{l}\text { Non-monetary } \\
\text { (intangible) }\end{array}$ & 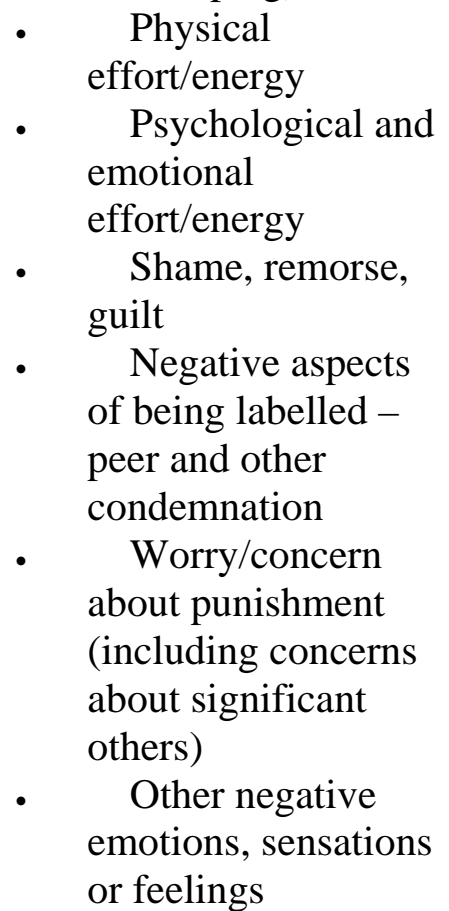 & $\begin{array}{ll}\text { - } & \text { Time and energy saved (from } \\
\text { - } & \text { Extting corners) } \\
\text { - } & \text { Feelings of control and power } \\
\text { over others } \\
\text { - } \quad \text { Feeling of freedom and control } \\
\text { over one's own acts } \\
\text { - } \quad \text { Potential boost to self-esteem } \\
\text { - Perceived extra sexual } \\
\text { - } \quad \text { Posportunities } \\
\text { labelled (kudos, peer and other } \\
\text { esteem) } \\
\text { Other positive emotions, } \\
\text { sensations, or feelings }\end{array}$ \\
\hline
\end{tabular}

Irrationality and the intuitive criminal

People make choices between criminal and non-criminal alternatives. Sometimes these are quick or impulsive decisions. Sometimes the decisions are based on imperfect information or perception, or impaired by alcohol, drugs or emotion. However flawed, they are nevertheless the product of a decision-making process. This is generally termed bounded rationality or limited rationality, attributed to Herbert Simon (1957, 1978), and widely used in criminology (e.g. Walsh 1986; Opp 1997; Brezina 2001; Wilkinson 2001). Although such decisions, particularly those relating to offending, are not 'rational' in the everyday sense of that word, they are made upon the platform of weighing perceived costs and benefits, that is, within the choice theory framework. This means impaired, poor, emotionally driven, or satisficing decisions that are 'irrational' fit into the rational choice framework, and can be caricatured as follows: 
o Intuitive and impulsive (including elements of emotional) decisions are not thought through: 'It seemed like a good idea'; 'I wasn't thinking'; 'I regret it now'; 'I was hot-headed'; 'It was spur-of-the-moment'.

o Imperfect decisions based on a lack of information: 'I didn’t know they had a dog/silent alarm/CCTV)'; 'At the time, I didn't think of the consequences'.

o Impaired (including emotional) decisions: 'I wasn't thinking straight'; 'It was the alcohol/drugs not me'; 'It was my uncontrollable teenage angst/contempt for society'; 'I was angry because he looked at my pint'.

Crime-specific examples may further illustrate bounded rationality in relation to SCP. Even the wildest or most bizarre and irrational crimes involve some degree of 'rational' decision-making. Gun-wielding mass murderers often make excellent choice of weaponry, vulnerable targets and suitable environments (think Dunblane, Columbine). Serial killers make remarkably sound choices of vulnerable victims and hide their tracks, sometimes for long periods (think Harold Shipman), sometimes forever (think Jack the Ripper). Arsonists, who are 'fire-setting' on Hayward's list, choose flammable targets and purchase accelerants, and usually set fires in places which will maximize damage and/or minimize detection (burned-out stolen cars), or maximize insurance claims (fraud). Even the most disturbed, flailing drunk knows who 'the enemy' is - it may be anybody in the vicinity - and attacks people with whatever tools are available (a beer bottle, a pint glass). Suicidal persons make 'rational', often ingenious, choices of a modus operandi, which is why shoelaces, belts and solid hanging points are removed from the cells of suicidal prisoners (see e.g. Hayes 1995). The heroin-dependent offender committing crime to fund a habit still 'rationally' tries to conceal their habit-feeding shoplifting, 'rationally' uses a weapon to increase success rates for street robbery, or 'rationally' robs the pharmacy not the shoe shop to find drugs. Trevor Bennett assessed heroin addiction from a rational choice perspective (Bennett 1986; see Becker and Murphy 1988 for a theory of rational addiction). From the perspective of SCP, then, which is the context for this discussion, even seemingly perverse and highly irrational behaviour still involves decisions with elements that mean the crimes are amenable to situational responses.

A specific aspect of bounded rationality that Hayward addresses at length relates to the immediacy or impulsivity of expressive crime and the apparent lack of deferred gratification of some offender decision-making, characterized as a 'culture of now' (pp. 238-9). Passing reference was made to the issue of discounting, but it seemed to be too quickly dismissed. Discounting is a process used in cost-benefit analysis to account for the influence of time upon preferences and value. The fact that preferences are time-sensitive (we prefer some things now but will defer others) is referred to as the social rate of time preference (Gramlich 1990). Time preferences can be exponential, hyperbolic if extreme, and can change or be inconsistent (O’Donoghue and Rabin 1999). Since different people have different preferences, they have different implicit discount rates in their decision-making. People with a preference for immediacy make different decisions from those made by people without such a preference. That is, discounting accounts for the 'now' preference in the decision-making of some individuals, and cannot be dismissed. Nor is it in choice theory. 


\section{Reflexions on Cultural Criminology}

There's no pleasing some people.

(Jesus, son of God, according to Monty Python's Life of Brian ${ }^{11}$ )

At this stage it would be remiss not to offer reflexions on Hayward's cultural criminology. What follows is based on Hayward (2007) plus an assessment of Hayward and Young's (2007) review essay, which is partly a response to O'Brien (2005). This is not a comprehensive review, so the reader should not generalize from the findings.

\section{Shopping for a theory}

Martin O’Brien identifies at least four key weaknesses in cultural criminology:

1. '[Cultural criminology] is characterized by important confusions over what is meant by "culture" in the analysis of deviant and criminal activity.'

2. '[T]he absence of detailed engagement with classic debates in social anthropology serves to undermine cultural criminology's assertion that the lens of culture provides a critical tool for understanding criminal acts.'

3. '[Cultural criminology] is characterized by a contradiction between its ethnographic imagination and its anthropological imagination,'

leading him to suggest that

4. '[T]he absence of a detailed theoretical account of culture renders cultural criminology vulnerable to Gouldner's (1975) charge that its practitioners represent contemporary “zoo-keepers” of deviance.' (O’Brien 2005: 599)

Confusion over the meaning of culture is 'found both in cultural criminology's key empirical works and in the emerging theoretical frameworks that seek to interpret crime through the lens of culture' (O’Brien 2005: 599). This lack of clarity and originality led O’Brien to conclude:

Of course, whether cultural criminology really does represent a new intellectual endeavour rather than a logical elaboration of previous work on deviant subcultures is itself debatable. (2005: 600)

In response to O’Brien, Hayward and Young state that cultural criminology has been around for fifteen years, but note that

[d]espite many positive developments, the trajectories and methods of cultural criminology have yet to be firmly established. (2007: 103)

This is not so much a refutation of O’Brien's criticisms as an admission that cultural criminology is adrift. In relation to more specific aspects of method, Hayward and Young propose that: 
A core methodological component of cultural criminology is therefore the scholarly reading of the numerous texts and images that circulate and promulgate the 'story' of crime and crime control within society. (2007: 108)

Reading, of the scholarly variety no less, is offered as a 'core methodological component' of cultural criminology.

\section{Liquid definitions}

Expressive crime appears to be a central concern of Hayward's (2007) cultural criminology. Yet it does not appear to be clearly defined, and implies a dichotomy of expressive and instrumental. As suggested already, this is clearly not the case - many, perhaps most, crimes labelled 'expressive' contain at least significant elements of instrumentality (Tedeschi and Felson 1994; Wilkinson 2001). Definitional and conceptual limitations may be inferred from the fact that Hayward's set of 'expressive' crimes (look back at table 1) appears to lack any obvious unifying concept. It also reads as oddly selective. Some of the set - skateboarding, street protesting and Parkour free running - are not even crimes. Their inclusion seems to mimic early deviancy studies that addressed issues such as the management of respectability in nudist camps and having breakfast with topless barmaids (Weinberg 1966, 1970, and Ames, Brown and Weinberg 1970, cited in Sparks 1980: 201). Jock Young noted of such work that

it is engaged in a remarkable accomplishment - the development of a criminology that does not deal with property crime, and a criminology whose subjects live not in a world of work but in a world of leisure. (Young 1975: 68-9, cited in Sparks 1980: 201)

Complementing this world of leisure, an overt celebration of offenders seems to appear in the representation of expressive offenders as 'urban-adventurer criminals' (p. 244). Is the physical injury and humiliation of a victim of happy slapping the work of modern-day Robin Hoods? This seems to ignore the harm experienced by victims. This is compounded by the term 'shallow-end crime' as Hayward uses it (pp. 236, 237), which could be interpreted as downplaying the experiences of victims of street crime.

In Hayward's assessment, injuries to victims seem to come across, to this reader at least, as a form of collateral damage, with capitalism indirectly to blame for friendly fire from alienated individuals referred to using Zygmunt Bauman's notion of 'sensation-gatherers' (p. 239). Sensation-gatherers are offered as the conceptual development of Marxism's traditional view of offenders as alienated 'soldierproducers' (p. 239). However, it seems to come across as a new bandwagon for much the same message. Sensation-gathering seems as ambiguously defined as the expressive crimes being committed. The term would appear to suggest there are some crimes for which no sensations are gathered. Moreover, the suggestion that it is only new sensations that are gathered by the offender who 'constantly craves new experience' (p. 239, emphasis in original) would seem to imply that an offender moves on after experiencing the sensation once, it no longer being new. If that is the case, it would limit the possibility for either repeat offending by the same crime type or for repeat victimization by the same offenders, making it irrelevant to a broad 
swath of crime and criminology. The term 'sensation-gathering' warrants examination. It could be said to sound as if offenders are strolling through a sweet summer meadow, and if so, that the term possibly results in a subtle romanticization of offending. When combined with urban-adventurer criminals in their world of leisure it is suggestive of some of the more inappropriate forms of cultural relativism. In the present context, however, and independent of the definition, sensations are benefits or costs that are incorporated in the decision-making process when committing crime, and hence in choice theory.

\section{Liquid criminology}

To this reader, cultural criminology's goals seem rather unclear. However, there is a hint of a crime reduction aim in Hayward's argument that crime problems can only be tackled by major structural social reform or 'macro-level socio-political intervention' (p. 235). 'Expensive' policies (p. 235) are alluded to that would reduce crime, but no further explanation is given. It is difficult to draw conclusions from such a brief allusion to a policy agenda.

In the broader context of this discussion it seems reasonable to suggest it is unlikely that cultural criminology has much to offer crime reduction. Such a possibility would sit well with O'Brien's (2005) suggestion that cultural criminology may be more of a style than a theory or approach. It would also seem to have parallels with the conclusion drawn nearly 30 years ago by Richard F. Sparks (1980), which was that Marxist criminology lacked a distinct criminological perspective (even though a distinction may be claimed between Marxist and post-Marxist perspectives). Nevertheless, the present writer would like to see Hayward's assertions regarding 'expensive' alternatives developed into a clear policy agenda with an explicit mechanism by which reductions in crime would be achieved.

\section{Liminal tendencies}

Rioting gives people a sense of community. And isn't that what we're all seeking in this age of computers and global warming?

(Police Chief Wiggum $^{12}$ )

An element of Hayward's argument is the repeated assertion that expressive crimes are rapidly growing in number:

- 'a growing number of so-called “expressive crimes”' (p. 233);

- 'the growing number of crimes containing a high emotional or "expressive" element' (p. 237);

- 'the type of expressive ('affective') crimes that are on the increase within contemporary consumer societies' (p. 242);

- 'the growing number of so-called expressive crimes' (p. 244).

It is unclear whether Hayward means the prevalence of expressive crime types or the incidence of all expressive crime, but it seems that little or no supporting evidence is presented for either. By 2007, most types of crime in England and Wales had been declining for the best part of a decade according to the most reliable indicators 
(Walker et al. 2006). The steep and prolonged decline in crime in the United States, the country most notably manifesting the consumerism that is cultural criminology's target, was perhaps most well known (see e.g. Blumstein and Wallman 2000). These trends may not suit Hayward's argument, but that does not mean they can be ignored.

Hayward refers to (but does not source) empirical evidence that binge drinking has increased (p. 238). Binge drinking may lead to crime although, as noted, many crime types decreased in the decade before Hayward's work. Hayward finds an increase in binge drinking odd and says we need to look 'at what has happened from a cultural perspective' (p. 238), but offers no further explanation. The explanation for an increase in binge drinking would most likely be found primarily in the laws of supply and demand: How could it not increase in the face of huge falls in the price of alcohol plus huge increases in availability from supermarkets and new bars? ${ }^{13}$ But more importantly, Hayward's use of empirical evidence to support an argument appears rather selective.

If cultural criminology may have a tendency to disregard empirical evidence, it would perhaps be complemented by the dismissal of the use of statistics and formulae. Along those lines, Hayward's assessment of Exum's use of a formula concludes:

Thus is the intractable question of criminality reduced to a two-inch formula at least for the purposes of statistical policy analysis. (Hayward 2007: 234)

The formula referred to is straightforward and represents offender decision-making as involving the weighing of perceived costs and benefits, or that 'all crime is a function of perceived pain and pleasures’ (Exum 2002: 957). Perhaps surprisingly, however, Hayward offers no substantive criticism of any component of the formula or any item of substance in Exum's article, just a dismissal. ${ }^{14}$ Such a view of 'statistical policy analysis' does not seem to be justified. It is, for the present writer, somewhat reminiscent of Irigaray's criticism of Einstein's $E=M c^{2}$ formula for 'privileging what goes the fastest' (see Sokal and Bricmont 1998: xix, 100; Dawkins 1998). In this reader's view, the wholesale dismissal of statistical method, when combined with further dismissive reference to an 'all-too-typical empirical study' (p. 237), falls some way short of constituting an informed critique. It would be a particularly narrow perspective that perceives no role for formulae or statistical policy analysis.

Following the wholesale dismissal of Exum's work, just three pages later, Hayward offers Exum's criticism of rational choice theory as support for his own argument, noting: 'One recent test of the RC perspective by Exum is particularly illuminating ... he states that "the $[\mathrm{RC}]$ perspective may not be the general explanation for crime it is proclaimed to be"' (p. 237). Having derided it, to then present the same work as 'for' the argument represents remarkable tolerance of cognitive dissonance. ${ }^{15}$

\section{Liminal tendencies II}

The first reference in the first paragraph of Hayward's article offers Farrell and Pease (2001) as containing a summary of Ken Pease's work on preventing repeat burglaries. It does not. ${ }^{16}$ However, this could be debated and a referencing error is arguably minor, but it was introduced here only as a prelude. Insight into Hayward's cultural criminology might be gleaned from the fact that Ronald Clarke is found to be the 
leading proponent of SCP and rational choice (p. 235) but there is no reference to any of Clarke's studies published in the previous decade, of which there are dozens, all relevant. However, the book by Clarke and Felson (1993: 6) is referred to. They argue that crime is

purposive behaviour designed to meet the offender's commonplace needs for such things as money, status, sex and excitement, and that meeting those needs involves the making of (sometimes quite rudimentary) decisions and choices, constrained as these are by limits of time and ability and the availability of relevant information.

This is fairly unambiguous and is representative of Clarke's work. It is unclear how it could be concluded from this that status, excitement and other intangible costs are not part of offender decision-making. The landmark book The Reasoning Criminal is also cited by Hayward. Its Introduction notes

the individual's recognition of his or her 'readiness' to commit the specific offense in order to satisfy certain needs for money, goods, or excitement. (Cornish and Clarke 1986: 4)

Several other chapters of that book are explicit on these issues, as are many criminological works, some referenced previously herein. More broadly speaking, an inspection of Hayward's reference list would lead an uninformed reader to suspect there was little or no work relating to SCP in the preceding decade, when this is not the case. This does not mean earlier works are properly addressed. For example, the possibility that SCP does not address expressive crime was raised by Trasler (1986) in a paper cunningly disguised as 'Situational crime control and rational choice: a critique' in Heal and Laycock's classic collection that appears on Hayward's list of references. It is difficult not to conclude that there are some significant omissions from the 2007 study, and that the resultant under-representation of the relevant literature may be partly responsible for some of the conclusions.

\section{Shopping for a theory II}

There does not appear to be a cohesive theory of the relationship between crime and culture that can be identified in Hayward's (2007) presentation of cultural criminology. References to a focus on 'complex existential motivations' of offenders (p. 236), 'the complex socio-cultural dynamics and existential dilemmas that are at the root of all crimes' (p. 246), and the 'subjective experiences and highly textured sociocultural situations behind all crimes' (p. 238) go largely unexplained. There is little revelation in observing that some crime may be partly due to teenage angst. In addition, most criminology that seeks to explain or understand criminality usually does so as a stepping stone to developing crime reduction policy and practice, but that does not seem to be the case here. More generally, cultural criminology appears to this reader to be a combination of existing elements of the sociology of deviance and some post-Marxist 'postmodernism', with rather confused consequences. It seems to play on the ambiguity of the term 'cultural', which could cover things including popular culture and the media, high culture and aesthetics, the Cultural Revolution in China, and cultural variations in habit and custom. However, making the simplifying 
assumption that culture refers to habits, customs and behavioural norms, let us ask two simple questions: What causes cultural change? How would cultural change cause crime? Put this way, it becomes apparent there is a powerful theory of crime and cultural change staring us in the face. It is termed routine activity theory.

Routine activity theory was originally published as a critical account of how socio-economic progress and the forces of capitalism caused crime, in Cohen and Felson's 'Social change and crime rate trends: a routine activity approach' (1979). It is pessimistic and prescient of the types of anti-globalization, anti-consumerist argument inherent in cultural criminology. It theorizes (see Felson 2002, for a more optimistic recent statement) crime as the product of social change, with the key driving forces being technological, socio-economic, environmental and political. The mechanism of change is the nature and frequency of interactions between suitable targets and potential offenders in the absence of capable guardians.

Routine activity theory helps understand how cultural change and variation drives crime. In this context, cultural changes tend to be changes in behaviour that are, when offending is the behaviour, induced by changes in criminal opportunities and provocations. So, progress brought more and better cars in the twentieth century, which changed our lives but also provided vast opportunities for car crime. And as society's mobility and movement patterns changed, so did its crime patterns. Television, iPods and mobile phones change our habits, behaviour and lifestyles (cultural change) and drive up theft rates. Happy slapping was facilitated by technological change - digital cameras, mobile phones and the Internet. The Internet facilitates cultural change and e-crimes (see Newman and Clarke 2003, on prevention), while globalization is suggested to have facilitated some forms of terrorism (see Clarke and Newman 2006, on prevention). Significant progress in transportation and telecommunications technologies in the twentieth century brought exponential growth in international exchanges, including trade and travel. The process brought national cultures closer together in the global village, while assisting and shaping crimes such as international drug trafficking (Keh and Farrell 1997; Farrell 1998). This is brief coverage but the key is that globalization and 'consumerist society' can drive up crime via criminal opportunities and provocations. So the present writer would propose that the best and most reflexive (in Hayward's terms) theory is routine activity theory, at least for those parts of cultural criminology that examine the relationship between cultural variation and crime.

\section{Conclusion}

The reader should not be fooled into thinking that the present author believes situational crime prevention has been universally successful or unproblematic. It is still very much in its infancy. Some crimes appear difficult to prevent by situational means, including some forms of violence where there has been little research to date. SCP must be ethical and have due regard for civil liberties, and where it does not it is bad practice - hence Clarke (2000) clearly distinguishes 'narrow' from 'broad' situational measures (see also Clarke 2006). Where behaviours are incorrectly prohibited, then it is the law that should change. There are clear instances where that has occurred, such as homosexuality, which was substantially decriminalized in England and Wales under the 1967 Sexual Offences Act. There is a major need for further work to stimulate corporate social responsibility in designing out crime. And SCP must, of course, be highly adaptive, to account for changing crime in a changing 
world. Alongside situational measures, other cost-effective approaches that reduce crime should prosper as complements, not substitutes. However, there is compelling evidence that Hayward's first thesis has been disproved: SCP has been applied to expressive crimes in many ways, and has the potential to be more widely applied in the future. There is also compelling evidence that Hayward's secondary thesis has been disproved and that in the context of informing SCP, rational choice theory applies to expressive and seemingly irrational criminal acts. The main conclusions of the present work can be summarized as five points:

1. Situational crime prevention is applicable to all crime types.

2. The rational choice perspective can be used to inform SCP in relation to all crime types including criminal acts labelled as expressive or irrational.

3. Harm-reducing situational measures are widely utilized in most areas of social policy and everyday life.

4. Cultural criminology seems to offer little, if anything, useful to inform crime reduction efforts.

5. Routine activity theory could prove useful to cultural criminology, as it is a powerful theory of the relationship between cultural variation and crime.

Cultural criminology was shown, using Hayward and Young's own words, to lack clear aims. It also seems to have no transparent definition of culture, no clear understanding of the concepts of expressive crime or sensation-gathering that it claims as key subject matter, and to offer no original theory of crime prevention. Its proponents seem to claim this mix as an advantage. Onlookers may suspect the emperor has no clothes.

Overall, the Hayward (2007) article seems to be characterized by a series of assertions that lack supporting argument or evidence. It appears to eschew empirical work at some times but to use it at others. While purporting to criticize situational crime prevention and rational choice, it seems that Hayward may have inadvertently exposed flaws in cultural criminology.

\section{Notes}

1. The Simpsons, season 7, episode 11: 'Marge Be Not Proud'.

2. References using page numbers only will be to Hayward's article.

3. Felson's theory can benefit from the simplifying assumption that criminal motivation is a given, but such assumptions are an important part of much theorizing. Elsewhere, rational choice is represented as claiming 'motivational comprehensiveness' (p. 235) when that is not even an aim in the context of SCP, where it is used to inform the development of crime prevention interventions.

Other perspectives linked to SCP are implicitly targeted by association, including environmental criminology (pp. 235-6), work on resource allocation to crime hot spots (p. 236) and crime pattern analysis (p. 236). A series of seemingly minor asides can influence the overall tone and content of a study. 
4. A Google search finds various gurus claiming or attributing the quote, but it is secular and mainly referenced as anonymous.

5. Many tactics in table 2 are accepted and everyday measures that are situational in a broad sense rather than in the narrower sense of being developed as a result of action research with problem identification and evaluation (see Clarke 2006).

6. Available at: www.popcenter.org/25techniques.

7. On YouTube at: www.youtube.com/watch?v=R6OaRcsfnY4 (accessed 16 June 2007).

8. See: www.securedcarparks.com.

9. Publications on tackling vandalism, with details on additional research, via www.crimereduction.homeoffice.gov.uk/vandalism01.htm

10. My apologies if such an account already exists: As with most of the crime types here, the intention is not a comprehensive review but only one sufficient to demonstrate the invalidity of Hayward's assertions.

11. Brian (Graham Chapman) said it, to which the ex-leper (Michael Palin) exclaimed, 'That's just what Jesus said, sir!'

12. Chief Wiggum, The Simpsons Movie (Twentieth Century Fox, 2007).

13. There are other factors, including new alcopops that attract young drinkers, 'happy hours' and other promotions and incentives, and increased disposable income among young people. Note Hayward's focus on change over time, not variation across places, where the explanation would be different (and where, say, cultural variation reflects legal and historical differences such as the British tradition of 11 p.m. closing time). Hayward also asserts binge drinking must be irrational ' $[u]$ nless, of course, one actually believes that people systematically and rationally set themselves the task of projectile vomiting in the street, falling asleep in doorways, or verbally abusing complete strangers' (p. 238), which falls under a lack of understanding of the non-monetary rewards of drinking and intoxicated behaviour (peer pressure, kudos, war stories, etc. - see also Assaad and Exum 2002).

14. Hayward states: 'Under the rubric of RC, the human purposes and existential meanings of crime are thus literally banned from the equation' (p. 234). In my view this mainly aspires to be facetious but, if not, it is factually incorrect. This is because, to the extent that meaning and purpose are not already included in the variables of Exum's table 4 (2002: 957), and could be further measured (perhaps as stated preferences, presuming Hayward could clarify what he means), they would be incorporated as components of $\mathrm{Xb}$ or $\mathrm{Xc}$ in the equation, that is, as elements of benefit or cost respectively.

15. Moreover, Exum's (2002) embryonic criticism of rational choice theory was unambiguously modified elsewhere in his work such that 'physical aggression can in fact be seen as a "rational" and opportune choice to the intoxicated offender' (Assaad and Exum 2002: 77).

16. Farrell and Pease (2001) is not a summary of anything - it is an edited book. There are two chapters on repeat burglary, by Edward Kleemans (2001) and Frank Morgan (2001), neither of which is or can be characterized as a summary of Pease's work on preventing repeat burglaries.

\section{References}


Akwagyiram, A. (2005), Does happy slapping exist? BBC News online (12 May). Available at: http://news.bbc.co.uk/1/hi/uk/4539913.stm

Assaad, J.-M. and Exum, M. L. (2002), Understanding intoxicated violence from a rational choice perspective. In A. R. Piquero and S. G. Tibbetts (eds), Rational Choice and Criminal Behavior: Recent Research and Future Challenges, London: Routledge, pp. 65-84.

Atkinson, G., Healy, A. and Mourato, S. (2005), Valuing the costs of violent crime: a stated preferences approach, Oxford Economic Papers, 57: 559-85.

BBC (2007), Contemporary art prices ‘up 55\%’, BBC News online (1 October). Available at: http://news.bbc.co.uk/1/hi/entertainment/7021703.stm

BBC (2008), Paper 'reveals Banksy identity', BBC News online (13 July). Available at: http://news.bbc.co.uk/1/hi/entertainment/7504132.stm

Beauregard, E. and Leclerc, B. (2007), An application of the rational choice approach to the offending process of sex offenders: a closer look at the decision-making, Sexual Abuse: A Journal of Research and Treatment, 19: 115-33.

Becker, G. S. and Murphy, K. M. (1988), A theory of rational addiction, Journal of Political Economy, 96, 4: 675-700.

Bennett, T. (1986), A decision-making approach to opioid addiction. In D. B. Cornish and R. V. Clarke (eds), The Reasoning Criminal: Rational Choice Perspectives on Criminal Offending, New York: Springer Verlag, pp. 83-102.

Blumstein, A. and Wallman, J. (2000), The Crime Drop in America, New York: Cambridge University Press.

Brezina, T. (2001), Assessing the rationality of criminal and delinquent behavior: a focus on actual utility. In A. R. Piquero and S. G. Tibbetts (eds), Rational Choice and Criminal Behavior: Recent Research and Future Challenges, London: Routledge, pp. 241-64.

Brown, R. (2004), The effectiveness of electronic immobilisation: changing patterns of temporary and permanent vehicle theft. In M. G. Maxfield and R. V. Clarke (eds), Understanding and Preventing Car Theft (Crime Prevention Studies, vol. 17), Monsey, NY: Criminal Justice Press, pp. 101-19.

Brown, R. and Thomas, N. (2003), Ageing vehicles: evidence of the effectiveness of new car security from the Home Office Car Theft Index, Security Journal, 16, 3: 45-54.

Clarke, R. V. (2000), Situational prevention, criminology, and social values. In A. von Hirsch, D. Garland and A. Wakefield (eds), Ethical and Social Perspectives on Situational Crime Prevention, Oxford: Hart, pp. 97-112.

Clarke, R. V. (2004), Technology, criminology and crime science, European Journal on Criminal Policy and Research, 10: 55-63.

Clarke, R. V. (2006), Seven misconceptions of situational crime prevention. In N. Tilley (ed.), Handbook of Crime Prevention and Community Safety, Cullompton: Willan, pp. 39-70.

Clarke, R. V. and Felson, M. (1993), Routine Activity and Rational Choice (Advances in Criminological Theory, vol. 5), New Brunswick, NJ: Transaction.

Clarke, R. V. and Newman, G. (2005), Modifying criminogenic products: what role for government? In R. V. Clarke and G. Newman (eds), Designing Out Crime from Products and Systems (Crime Prevention Studies, vol. 18), Cullompton: Willan, pp.7-83 . .

Clarke, R. V. and Newman, G. (2006), Outsmarting the Terrorists, New York: Praeger. 
Cohen, M. (2000), Measuring the costs and benefits of crime and justice. In Crime and Justice 2000. Vol. 4: Measurement and Analysis of Crime and Justice, Washington, DC: National Institute of Justice, pp. 263-315.

Cohen, L. E. and Felson, M. (1979), Social change and crime rate trends: a routine activity approach, American Sociological Review, 44: 588-605.

Cohen, M., Rust, R. T., Steen, S. and Tidd, S. T. (2004), Willingness-to-pay for crime control programs, Criminology, 42, 1: 89-109.

Cornish, D. B. (1978), Gambling: A Review of the Literature, Home Office Research Study 42. London: HMSO.

Cornish, D. B. (1993), Theories of action in criminology: learning theory and rational choice approaches. In R. V. Clarke and M. Felson (eds), Routine Activity and Rational Choice (Advances in Criminological Theory, vol. 5), New Brunswick, NJ: Transaction, pp. 351-82 .

Cornish, D. B. (1994), The procedural analysis of offending and its relevance for situational prevention. In R. V. Clarke (ed.), Crime Prevention Studies, vol. 3, Monsey, NY: Criminal Justice Press, pp. 151-93.

Cornish, D. and Clarke, R. (1986), Introduction. In D. B. Cornish and R. V. Clarke (eds), The Reasoning Criminal: Rational Choice Perspectives on Criminal Offending, New York: Springer Verlag, pp. 1-16. Available at: www.popcenter.org/library/reading/PDFs/ReasoningCriminal/01_introduction .pdf

Cornish, D. B. and Clarke, R. V. (1987), Understanding crime displacement: an application of rational choice theory, Criminology, 25: 933-47.

Cornish, D. B. and Clarke, R. V. (2003), Opportunities, precipitators and criminal decisions: a reply to Wortley's Critique of Situational Crime Prevention. In M. Smith and D. Cornish (eds), Theory for Practice in Situational Crime Prevention, vol. 16 of Crime Prevention Studies, Monsey, NY: Criminal Justice Press, pp. 41-96.

Darker, I., Gale, A. G., Ward, L., Blechko, A. and Purdy, K. (2007), Lights, camera, action and arrest. In P. D. Bust (ed.), Contemporary Ergonomics 2007, London: Taylor and Francis, pp. 171-7.

Darwin, C. (1859) [reproduced 1975], On the Origin of Species, Cambridge, MA: Harvard University Press.

Dawkins, R. (1998), Postmodernism disrobed, Nature, 394: 141-3. Available at: http://richarddawkins.net/article,824,Postmodernism-Disrobed,RichardDawkins-Nature (accessed November 2007).

Dawkins, R. (2003), Unfinished correspondence with a Darwinian heavyweight. In $A$ Devil's Chaplain: Selected Writings, London: Weidenfeld and Nicolson, pp. 218-22.

Dolan, P., Loomes, G., Peasgood, T. and Tsuchiya, A. (2005), Estimating the intangible victim costs of crime, British Journal of Criminology, 45, 6: 95876.

Dubourg, R., Hamed, J. and Thorns, J. (2005), The Economic and Social Costs of Crime against Individuals and Households 2003/4, Home Office Online Report 30/05, London: Home Office.

Ekblom, P. (1997), Gearing up against crime: a dynamic framework to help designers keep up with the adaptive criminal in a changing world, International Journal of Risk, Security and Crime Prevention, 2, 4: 249-65.

Ekblom, P. (1999), Can we make crime prevention adaptive by learning from other evolutionary struggles? Studies on Crime and Crime Prevention, 8: 27-51. 
Erez, E. and Ibarra, P. R. (2007), Making your home a shelter: electronic monitoring and victim re-entry in domestic cases, British Journal of Criminology, 47, 1: 100-20.

Exum, M. L. (2002), The application and robustness of the rational choice perspective in the study of intoxicated and angry intentions to aggress, Criminology, 40, 4; 933-66.

Farrell, G. (1998), Routine activities and drug trafficking: the case of the Netherlands, International Journal of Drug Policy, 9: 21-32.

Farrell, G. and Pease, K. (eds) (2001), Repeat Victimization (Crime Prevention Studies, vol. 12), Monsey, NY: Criminal Justice Press.

Farrington, D. P. (1993), Understanding and preventing bullying. In M. Tonry (ed.), Crime and Justice: An Annual Review of Research, vol. 17, Chicago: University of Chicago Press, pp.381-458.

Feeney, F. (1986), Robbers as decision-makers. In D. B. Cornish and R. V. Clarke (eds), The Reasoning Criminal: Rational Choice Perspectives on Criminal Offending, New York: Springer Verlag, pp. 53-71. Available at: www.popcenter.org/library/reading/PDFs/ReasoningCriminal/04_feeney.pdf

Felson, M. (1986), Linking criminal choices, routine activities, informal control, and criminal outcomes. In D. B. Cornish and R. V. Clarke (eds), The Reasoning Criminal: Rational Choice Perspectives on Criminal Offending, New York: Springer Verlag, pp. 120-8.

Felson, M. (2002), Crime and Everyday Life (3rd edn), Thousand Oaks, CA: Sage.

Felson, M. and Clarke, R. V. (1995), Routine precautions, criminology, and crime prevention. In H. D. Barlow (ed.), Crime and Public Policy: Putting Theory to Work, Boulder, CO: Westview Press, pp. 179-90.

Godson, E. and Farrell, G. (2005), Are Britain's higher education institutions prepared for prosecution in September 2005 due to their lack of disabled access? Review of Disability Studies: An International Journal, 1, 4: 56-63.

Gouldner, A. W. (1975), For Sociology, Harmondsworth: Penguin.

Gramlich, E. M. (1990), A Guide to Benefit-Cost Analysis (2nd edn), Prospect Heights, IL: Waveland Press.

Hayes, L. M. (1995), Prison Suicide: An Overview and Guide to Prevention, US Department of Justice, National Institute of Corrections.

Hayward, K. (2007), Situational crime prevention and its discontents: rational choice theory versus the 'culture of now', Social Policy \& Administration, 41, 3: 232-50.

Hayward, K. and Young, J. (2007), Cultural criminology. In M. Maguire, R. Reiner and R. Morgan (eds), The Oxford Handbook of Criminology, Oxford: Oxford University Press, pp. 102-21.

Hoare, J. and Cotton, J. (2006), Property crime. In A. Walker, C. Kershaw and S. Nicholas (eds), Crime in England and Wales 2005/6, Home Office Statistical Bulletin 12/06, London: Home Office, pp. 85-108.

Homel, R. (ed.) (1997), Policing for Prevention: Reducing Crime, Public Intoxication and Injury (Crime Prevention Studies, vol. 7), New York: Criminal Justice Press. Available at:

www.popcenter.org/Library/CrimePrevention/Volume\%2007/index.htm

Home Office (Economics and Resource Analysis Strategic Policy Team) (2006), Changing Behaviour to Prevent Crime: An Incentives-based Approach, Home Office Online Report 05/2006. Available at: 
www.homeoffice.gov.uk/rds/pdfs06/rdsolr0506.pdf (accessed November 2007).

Kahneman, D. (2002), Maps of bounded rationality: a perspective on intuitive judgment and choice. Nobel Prize Lecture, Aula Magna, Stockholm University, 8 December. Available at: http://nobelprize.org/nobel_prizes/economics/laureates/2002/kahnemanlecture.pdf (reproduced in American Economic Review [2003], 93, 5: 144975).

Keh, D. and Farrell, G. (1997), Trafficking drugs in the global village, Journal of Transnational Organized Crime, 3, 2: 90-101.

Kelling, G. and Sloan-Hewitt, M. A. (1992), Subway graffiti in New York City: “Getting' Up” vs. “Meanin' it and “Cleanin' it” . In R. V. Clarke (ed.), Situational Crime Prevention: Successful Case Studies, Albany, NY: Harrow and Heston, pp.242-249.

Kleemans, E. R. (2001), Repeat burglary victimisation: results of empirical research in the Netherlands. In G. Farrell and K. Pease (eds), Repeat Victimization (Crime Prevention Studies, vol. 12), Monsey, NY: Criminal Justice Press, pp. 53-68.

Lloyd, S., Farrell, G. and Pease, K. (1994), Preventing Repeated Domestic Violence: A Demonstration Project in Merseyside, Crime Prevention Unit paper 49, London: Home Office Police Research Group. Available at: www.popcenter.org/problems/witness_intimidation/PDFs/LloydEtal_1994.pdf

McFadden, D. (2000), Economic choices. Nobel Prize Lecture, Aula Magna, Stockholm University, 8 December. Available at: http://nobelprize.org/nobel_prizes/economics/laureates/2000/mcfaddenlecture.pdf

McFadden, D. (2001), Economic choices, American Economic Review, 91, 3: 351-78.

Mayhew, P. (1992), Steering column locks and car theft. In R. V. Clarke (ed.), Situational Crime Prevention: Successful Case Studies (1st edn), Albany, NY: Harrow and Heston, pp. 52-65.

Miller, T., Cohen, M. A. and Wiersema, B. (1996), Victim Costs and Consequences: A New Look, National Institute of Justice Research Report, Washington, DC: NIJ.

Morgan, F. (2001), Repeat burglary in a Perth suburb: indicator of short-term or longterm risk? In G. Farrell and K. Pease (eds), Repeat Victimization (Crime Prevention Studies, vol. 12), Monsey, NY: Criminal Justice Press, pp. 83-118.

Nee, C. and Meenaghan, A. (2006), Expert decision-making in burglars, British Journal of Criminology, 46: 935-49.

Newman, G. and Clarke, R. V. (2003), Superhighway Robbery: Crime Prevention and E-Commerce, Cullompton: Willan.

O'Brien, M. (2005), What is cultural about cultural criminology? British Journal of Criminology, 45: 599-612.

O’Donoghue, T. and Rabin, M. (1999), Doing it now or later, American Economic Review, 89, 1: 103-24.

Opp, K.-D. (1997), Limited rationality and crime. In G. Newman, R. V. Clarke and S. G. Shoham (eds), Rational Choice and Situational Crime Prevention, Aldershot: Ashgate, pp. 47-63.

PA Consulting (2004), Denying Criminals the Use of the Road, Report for the Home Office and the Association of Chief Police Officers, London: PA Consulting. 
Available at: http://police.homeoffice.gov.uk/publications/operationalpolicing/ANPR_10,000_Arrests.pdf?view=Binary

Pease, K. (1997), Predicting the future: the roles of routine activity and rational choice theory. In G. Newman, R. V. Clarke and S. Shoham (eds), Rational Choice and Situational Crime Prevention: Theoretical Foundations, Aldershot: Ashgate, pp. 233-245.

Pease, K. (1998), Crime, Labour, and the wisdom of Solomon, Policy Studies, 19, 3/4: 255-65.

Pitts, J., and Smith, P. (1995), Preventing School Bullying, Police Research Series, Paper 63, London: Home Office.

Sampson, A. and Phillips, C. (1995), Reducing Repeat Racial Victimisation on an East London Estate, Crime Detection and Prevention series paper 67, London: Police Research Group. Available at: www.homeoffice.gov.uk/rds/prgpdfs/fcdps67.pdf

Simon, H. (1957), Models of Man: Mathematical Models on Rational Human Behaviour in a Social Setting, New York: John Wiley.

Simon, H. (1978), Rational decision-making in business organization. Nobel memorial lecture, 8 December. Available at: http://nobelprize.org/nobel_prizes/economics/laureates/1978/simon-lecture.pdf

Smallbone, S. K. and Wortley, R. K. (2001), Child Sexual Abuse: Offender Characteristics and Modus Operandi, Trends and Issues in Crime and Criminal Justice, no. 193, Canberra: Australian Institute of Criminology.

Smith, J. (2003), The Nature of Personal Robbery, Home Office Research Study 254, London: Home Office.

Smith, M. J. (2003), Exploring target attractiveness in vandalism: an experimental approach. In M. J. Smith and D. B. Cornish (eds), Theory for Practice in Situational Crime Prevention (Crime Prevention Studies vol. 16), Monsey, NY: Criminal Justice Press, pp. 197-236.

Snyder, G. J. (2006), Graffiti media and the perpetuation of an illegal subculture, Crime, Media, Culture, 2, 1: 93-101.

Sokal, A. and Bricmont, J. (1998), Intellectual Impostures: Postmodern Philosophers' Abuse of Science, Delhi: Replika Press (2004 edition).

Southall, D. and Ekblom, P. (1985), Designing for Car Security: Towards a Crime Free Car, Crime Prevention Unit paper 4, London: Home Office.

Sparks, R. F. (1980), A critique of Marxist criminology. In N. Morris and M. Tonry (eds), Crime and Justice: A Review of Research, vol. 2, Chicago: University of Chicago Press, pp.159-210 .

Spicer, V . (2007), The portrait of a vandal: how Vancouver reduced graffiti by $80 \%$ over three years. Presentation to the 18th Annual Problem-Oriented Policing Conference held at Madison, Wisconsin.

Taylor, The Rt Hon. Lord Justice (1990), The Hillsborough Stadium Disaster, 15 April 1989: Final Report, London: HMSO.

Taylor, P., Hoare, J. and Murphy, R. (2007), Property crime. In S. Nicholas, K. Kershaw and A. Walker (eds), Crime in England and Wales 2006/7, Home Office Statistical Bulletin, London: Home Office, pp.73-94.

Tedeschi, J. T. and Felson, R. (1994), Violence, Aggression, and Coercive Actions, Washington, DC: American Psychological Association.

Thaler, R. H. and Sunstein, C. R. (2008), Nudge: Improving Decisions about Health, Wealth and Happiness, New Haven, CT: Yale University Press. 
Tibbetts, S. G. and Gibson, C. L. (2001), Individual propensities and rational decision-making: recent findings and promising approaches. In A. R. Piquero and S. G. Tibbetts (eds), Rational Choice and Criminal Behavior: Recent Research and Future Challenges, London: Routledge, pp. 3-24.

Trasler, G. (1986), Situational crime control and rational choice: a critique. In K. Heal and G. Laycock (eds), Situational Crime Prevention: From Theory into Practice, London: HMSO, pp. 17-24.

Tversky, A. (1967), Utility theory and additivity analysis of risky choices. Journal of Experimental Psychology, 75, 1: 27-36.

Tversky, A. and Kahneman, D. (1974), Judgement under uncertainty: heuristics and biases, Science, 185: 1124-1131.

University of Leicester, Centre for the Sociology of Sport (2001), Football and Football Hooliganism, Fact Sheet 1, Leicester: University of Leicester.

Walker, A., Kershaw, C. and Nicholas, S. (2006), Crime in England and Wales 2005/6, Home Office Statistical Bulletin 12/06, London: Home Office.

Walsh, D. (1986), Victim-selection procedures among economic criminals: the rational choice perspective. In D. B. Cornish and R. V. Clarke (eds), The Reasoning Criminal: Rational Choice Perspectives on Criminal Offending, New York: Springer Verlag, pp. 39-52.

Webb, B. (1997), Steering column locks and motor vehicle theft: evaluations from three countries. In R. V. Clarke (ed.), Situational Crime Prevention:

Successful Case Studies (2nd edn), Albany, NY: Harrow and Heston, pp. 4658.

Webb, B. (2005), Preventing car crime. In N. Tilley (ed.), Handbook of Crime Prevention and Community Safety, Cullompton: Willan, pp. 458-85.

Webb, B., Brown, B. and Bennett, K. (1992), Preventing Car Crime in Car Parks, Crime Prevention Unit paper 32, London: Home Office.

Wilkinson, D. L. (2001), Decision making in violent events among adolescent males: an examination of sparks and other motivational factors. In A. R. Piquero and S. G. Tibbetts (eds), Rational Choice and Criminal Behavior: Recent Research and Future Challenges, London: Routledge, pp. 163-96.

Wortley, R. (2006), Sexual abuse of children: can situational prevention work? Presentation to the 17th Annual Problem-Oriented Policing Conference held at Madison, Wisconsin. Available at: www.popcenter.org/conference/conferencepapers/2006/WortleySexAbuse.pdf Wortley, R. and Smallbone, S. (2006), Situational Prevention of Child Sexual Abuse (Crime Prevention Studies, vol. 19), Monsey, NY: Criminal Justice Press. 